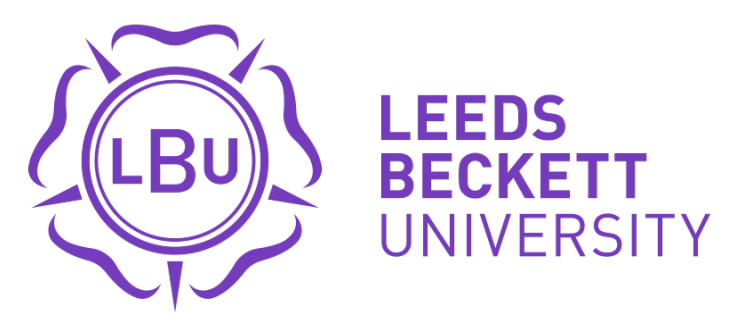

Citation:

Gold, J and Devins, D (2014) Re-conceptualising talent management and development within the context of the low paid. Human Resource Devopment International, 17 (5). 514 - 528. ISSN 1469-8374 DOI: https://doi.org/10.1080/13678868.2014.954191

Link to Leeds Beckett Repository record:

https://eprints.leedsbeckett.ac.uk/id/eprint/1498/

Document Version:

Article (Accepted Version)

The aim of the Leeds Beckett Repository is to provide open access to our research, as required by funder policies and permitted by publishers and copyright law.

The Leeds Beckett repository holds a wide range of publications, each of which has been checked for copyright and the relevant embargo period has been applied by the Research Services team.

We operate on a standard take-down policy. If you are the author or publisher of an output and you would like it removed from the repository, please contact us and we will investigate on a case-by-case basis.

Each thesis in the repository has been cleared where necessary by the author for third party copyright. If you would like a thesis to be removed from the repository or believe there is an issue with copyright, please contact us on openaccess@leedsbeckett.ac.uk and we will investigate on a case-by-case basis. 
Re-conceptualising talent management and development within the context of the low paid

David Devins and Jeff Gold

Faculty of Business and Law, Leeds Metropolitan University, Leeds, United Kingdom

Dr David Devins, Room Room 562, Rose Bowl Portland Cresent, Leeds Metropolitan

University, Leeds LS1 3HB, d.devins@leedsmet.ac.uk 


\title{
Re-conceptualising talent management and development within the context of the low paid
}

\author{
Those working in organisations have choices to make not only associated with \\ the goods and services they produce but also their wider social and economic \\ impact. The number of employees in low skilled/low paid jobs and the high \\ proportion of companies adopting business strategies based on low-specification \\ goods and services are a concern for many developed and developing economies. \\ Addressing this problem is not traditionally the concern of Human Resource \\ Development however we argue that through exploring the role that a wider, \\ more balanced approach to Sustainable Talent Management and Development (S- \\ TMD) may play within the context of the low skilled in the UK provides a crucial \\ link to enhancing an organisation's performance and responsibility to society. At \\ the heart of this approach lies a shift to appreciate the collective endeavour of \\ work practices, an enhanced role for stakeholders and identification of, and \\ participation in skills eco-systems to support sustainable development. The paper \\ identifies the opportunity for S-TMD to move from a predominantly \\ individualist, managerial and unitarist understanding to one grounded in the value \\ of tacit and embedded development processes undertaken to reflect a pluralist, \\ multi-voiced approach to understanding of a skills eco-system.
}

Keywords: Talent Management and Development, sustainability, corporate social responsibility, learning at work, stakeholders, poverty

\section{Introduction}

Garavan and McGuire (2010) have argued that Human Resource Development (HRD) needs to look beyond performance and learning issues that feed organisation efficiency to consider issues of sustainability and Corporate Social Responsibility (CSR). While it is well recognised that such terms lack clear definition and are broad in scope, it is still possible for those in organisations, including HRD professionals, to make choices on the basis of a wider awareness of social, environmental and economic issues (Van Marrewijk 2003). In this paper, we want to consider one such issue - the problem of low skill both within organisations and society beyond. We propose that one 
route into this issue is via Talent Management (TM), which in spite of its growing popularity and more than a decade of debate, retains considerable conceptual confusion and lack of clarity regarding definition, scope and overall goals (Thunnissen et al. 2013; Gallardo-Gallardo et al. 2013; Collings and Mellahi 2009; Lewis and Heckman 2006).

Next to leadership development, value-based recruitment and performance management, TM is seen as one of the key themes in human resources (Paawe 2007). For those in HRD, there have been warnings about the danger of connecting to what may be a TM fashion which is practised by organisations of high status (Iles et al. 2010). TM may also be just a new way for a repackaging of HR practices which does not represent anything particularly new (Chuai et al. 2008). However, more than 10 years after Michaels et al. (2001) declared the 'war for talent', and while there has been some doubts about its continuation as a movement, it does seem, at the level of discourse at least, that TM will continue as an 'essential management practice' (CIPD 2014). If this is the case, HRD has to join the game but on the basis of some serious questions, such as those prompted by Iles et al. (2010) and Iles (2013). For example; What issues is TM meant solve? What should be the focus of TM practices? If those identified as the talented are the target for TM, what about those not identified as the talented?

In this paper, we will draw on concepts from labour market and organisational development theory to place TM within a wider sustainability context. Much of the literature relating to sustainability tends to focus on a win-win-win situation but it may not be easy in many organisations to create economic efficiency, ecological and social sustainability simultaneously without a fundamental change in business strategy. A key interpretation of sustainability refers to a shift in emphasis in the definition of corporate success towards one where ecological and social performance is seen as being as 
important as financial performance (Enhert and Harry 2012). In this paper we seek to emphasize social sustainability and how organisational activities affect the people that they employ and society more generally (Pfeffer 2010). We propose to take up the questions prompted by Iles and in doing so, we wish to clearly state that HRD theory and practice must participate in responding. We suggest that since HRD is concerned with learning processes by individuals, groups and organisations, TM practices must lead and support this. Therefore, we wish to immediately extend TM to Talent Management and Development (TMD). We also wish to consider the issue of low skills and its association with low pay and how this might result in low paid and low skilled staff being excluded from TMD. This paper therefore seeks to contribute to the literature by exploring the role that a wider and more balanced approach to TMD may play in the development of a more sustainable society where interconnected economic and social aspects of development are considered. We will argue that an extended approach to TMD has the potential to lead to an appreciation of the learning that is embedded in the collective efforts and routines where talent in enacted at work and that sustainable TMD (S-TMD) has a key role to play in improving organisational performance as well as enhancing wider societal impacts.

\section{The problem}

Recently, in a review of the literature, Thunnissen et al. (2013) identified the lack of consideration of economic and non-economic values of TMD at the societal level. Instead the mainstream literature takes a narrower view and gives emphasis to the recruitment, development and retention of the talents of individuals that directly benefit the organisation. The approach is predominantly managerialist and unitarist. Further, there is an emphasis on the practices of recruitment, development and retention but very little consideration of what happens in employment, including the design and 
performance of work, the engagement and commitment to work and the context of work. Recent surveys of TMD practices in UK organisations suggest that it is exclusively senior managers and those categorised as high potentials who are the main targets, even though it was accepted that such a focus has significant de-motivating effects on others (CIPD 2013). What happens within organisations has potential negative effects on groups within the labour market and society more generally. Such effects are neglected in the TMD literature and little attention is paid to the responsibility of organisations for those not identified as talented. Further, much of the accepted meaning of TMD is based on a narrow conception of organisation goals, tied to a predominantly unitarist, economic purpose (Cappelli 2008).

In an era of increasing global competition, with ready transfer of processes through modern technology, national economies need to compete through the production of high-value goods and services. This represents a structural change with many economies increasingly based on knowledge, rather than routine production and with new jobs created in large numbers in high-skill/high wage professional and managerial occupations. The UK requires a skilled workforce and there is disturbing evidence that it lags behind its international competitors. The UK has traditionally faced a cycle of low value-added, low skills and wages where products and services are specified in low skill terms to keep costs down (Wilson and Hogarth 2003). The economy is characterised as one where a relatively high proportion of companies adopt business strategies based on low specification goods and services in which the demand for high-level skills is relatively low but the propensity for low wages and the underutilisation of skills in the workplace is high and increasing over time (UKCES 2009).

A further dimension of the problem relates to the structural changes in the labour market. Autor (2010) argues that technological change and the resulting hollowing out 
of internal labour markets has seen middle-skilled jobs disappear at a faster rate than low-paid, unskilled work. This is a process that limits the opportunities for those in the lower levels of the hierarchy to progress through the intermediate and middle levels. Gallie (2007) sums up a trend, reflecting concerns about the emergence of a dual labour market with separate primary and secondary sectors where the former contains higher skilled, better-paid and more secure jobs that provide opportunities for progression, learning and development and the latter contains increasingly precarious and low paid jobs where opportunities for learning and development are often absent. The latter may also include those identified as the Precariat, a new class who enjoy no job security, often suffering zero hour contracts as well as low pay and little social protection (Atkinson 2010).

Brockmann et al. (2011) point to the cultural difference between how work is conceived in the UK and overseas. In comparator countries, development and progression is often an integral aspect of most occupations whereas in the UK there are often limited opportunities to progress. A common way to differentiate low-skilled workers is to use pay levels as a proxy as low skills and low pay are often closely related. In many cases, the income of low-skilled workers is below thresholds established by Minimum Wages in countries where they exist (see ILO 2013 for a full discussion of the International dimension) or the proportions of workers falling below a certain pay threshold (OECD 1996). However not all low paid workers are low skilled and concerns have arisen associated with the underutilisation of skills by some higher skilled workers (particularly graduates) employed in low paid work (Felstead et al. 2007; Okay-Sommerville and Scholarios 2013) which could impact on HRD decision making. 
In addition and related to the low skill problem is the issue of the growth of inwork poverty. Policy-makers identify entry and progression in the labour market as a significant factor contributing to the alleviation of poverty and social inclusion. However, a body of research shows that entering work does not provide a sustainable route out of poverty if the quality of the job in terms of, for example, job security, low pay and lack of progression is not addressed (Gouldon 2010). More than $5 \%$ of jobs in the UK are what the Low Pay Commission (Pennycook and Whittaker 2012) describe as minimum wage jobs and approximately 20\% of employees (about 5 million) earn less than what is referred to as the living wage, a calculation of a wage that is based on what is needed by an average household to cover basic living costs. A similar proportion earns less than the commonly used low-pay threshold for OECD countries. Crossborder differences in the incidence of low pay between developed countries suggest that distinct social and policy models are at play. For example, being employed in consumer services carries a much bigger risk of low pay in the UK than in most other advanced economies, some of which have built institutions, including more assertive minimum wage strategies and social partners that encourage employers to provide 'better quality' employment (Plunkett and Hurrell 2013).

The fact that low pay is widespread in the economy but mainly concentrated in some sectors and types of organisation makes it difficult for policy makers to intervene and raise wages when businesses may not be able to absorb the costs and remain competitive. Addressing the problem of low pay may not traditionally be the concern of mainstream HRD however the limits in policy options such as the national minimum wage, the living wage and tax credits have led to an interest in public policy alternatives that relate directly to learning and development in the workplace and which are central to TMD (Philpott 2014). 


\section{Theoretical and conceptual framework}

Although 'talent' is a term in widespread use, its use in HRD is varied and can cause confusion. For example, some see talent consisting of those individuals who can make a difference to organisational performance, whether through their immediate contribution or in the longer term by demonstrating high levels of potential (Tansley et al. 2007). Others see it in everyone, inherent in each individual realising their potential (Redford 2005). A further alternative view sees talent as a collective phenomenon, to be explored in team-based ways with attention focussed on social capital, teamwork, leadership and networks (Iles et al. 2010).

In a review of the literature Gallardo-Gallardo et al. (2013) propose that two approaches are important in defining talent in the context of the world of work. The first makes a distinction between talent as characteristics of people (object approach) and the second talent as people (subject approach). Within the object approach, talent is conceptualised as exceptional abilities and attitudes demonstrated by an individual with a range of complimentary measures of ability including natural ability, mastery of a particular practice, commitment (both to one's own work and to the employing organisation) and fit (between the individual's talent and the work context). In this way it connects with a concept of skills as conceived in the economic/public policy domain by Buchanan et al. (2010). This conception recognises a comprehensive understanding of skill that takes into consideration three aspects: behavioural (the personal qualities of the worker to deal with interpersonal relationships), cognitive (level and kind of education and training undertaken to help understand and act in the world) and technical (the capacity to undertake particular set tasks).

The subject approach embodies both an inclusive (i.e. talent understood as all employees of an organisation) and exclusive (i.e. talent understood as an elite subset of 
an organisation's workers) approach to TMD. The inclusive approach is based on the premise that every employee has his or her own strengths and, given an opportunity to develop and apply their knowledge and skills, can potentially create added value for the organisation. Within the global multinational corporation context, some authors recognize the potential of a talent management system open to all employees as a step in the overall careers of individuals (Cerdin and Brewster 2014).

The exclusive approach is based on the segmentation of the workforce and the identification of a select group of employees who rank at the top in terms of capability and performance. Exclusive approaches to TMD tend to dominate in developed and in developing countries such as India and China (Cooke et al. 2014). In theory at least there is no reason why the low-paid could not feature as an 'exclusive' group in a segmented workforce given the important contribution that they make to the customer experience in many sectors although as one might anticipate they seldom (if ever) do.

In labour market terms, global competition and the developing knowledge economy increases demand for highly qualified workers and, as the imperative to compete on quality increases, it focuses HRD on the processes required to equip organisations for the transition to higher quality business models. Much of the TMD literature, both professional and academic can be characterised as managerialist and is presented as a set of tools to manage talent effectively so that individual and organisational performance is under control and can be improved (Thunnissen et al. 2013). The literature usually assumes the individual as a unit of analysis and TMD is often narrowed down to the impact of a set of HR practices and activities that emphasize those used to recruit, motivate, develop, retain and terminate individual employees. Differences exist within and between HR practices but most chime with the purpose and concepts underpinning strategic HRD and revolve around the importance 
of a clear and consistent sense of organisational purpose and values (determined by senior management) to attract and inspire employees, and the development and implementation of appropriate HRD policies and practices. Sonnenberg et al. (2014) found an increased use of TMD practices is related to higher psychological-contract fulfilment, although success depends on matching the talent perceptions of the employer and the employee.

Formal HRD is an important dimension in the development of the knowledge and skills necessary to remain in and progress in work. However, much learning and development occurs outside the direct influence of formal HRD activities. If we move to include work practices in the conceptualisation of TMD, it could enable organisations to apply a wider set of practices and activities than the limited set often discussed in the TMD literature. Work practices are rarely taken into account as TMD practices and as a consequence the TMD literature consistently overestimates the importance of human capital and underestimates the impact of work processes. Borrowing from the research on distributed leadership (Gronn 2002; Spillane 2006), this suggests that the performance of work, whatever the formal design of work, is a collective endeavour requiring a unit of analysis beyond the focus on single individuals, positions or roles. So much of the enactment of work practice requires conjoint action based on varying degrees of dependence, interdependence and mutuality. It has long been recognised that repeated interactions result in an intuitive pattern of work relations, giving rise to various forms of tacit knowledge recognized as a crucial feature of workplace learning and knowledge creation (Beckett and Hager 2002). The significance of these considerations, from a TMD perspective, is to make greater efforts to connect employment and work practices, involving the organisation and structuring of work (Boxall and Macky 2009) and recognition of the importance of financial and non- 
financial rewards (Rubery and Grimshaw 2003). To date, theory in TM and/or TMD has paid scant attention to work as a collective endeavour. This suggests a need to shift the focus of theoretical work towards work practices based on dependence and interdependence.

Thunnissen et al. (2013) draw attention to the unitarist approach adopted in the literature associated with TMD. Top management, line management and HR professionals are all attributed a significant role in TMD with the underlying assumption that all these organisational actors share mutual goals and interests (Burbach and Royle 2010; Farndale et al. 2010). A few publications refer to the potentially conflicting goals and needs of different internal stakeholders in terms of for example short-termism and the focus on one part of the organisation rather than the whole (e.g. Martin and Schmidt 2010). Our reorientation of TMD towards the collective endeavours of organising demands a pluralist and therefore multi-voiced understanding. Pluralism recognises the differing goals, preferences and views of different stakeholders in TMD. Thunnissen et al. (2013) argue that adopting this view towards TMD entails recognising the needs, preferences and beliefs of stakeholders beyond management and has an impact on the employee-organisation relationship and its outcomes. However, much of the collective endeavour we refer to is likely to remain unseen by a unitarist and top-down approach adopted by organisations. This is likely to miss the significant potential for learning that is embedded in the relationships that are formed through work. Tacit knowledge, as the sociologist Collins (2001) has explained can take a variety of forms, including concealed knowledge but also knowledge which can be passed on and demonstrated to others as intelligence for corporate decision-making on strategy if they care to ask or find out. For HRD practitioners, we would suggest that an uncovering of how talent is being employed within work relationships becomes an 
important part of their work. To do this, they must begin a process of inquiry into the nature of conjoint activity within organisations, of whatever size, so that the significant potential for learning can be revealed. That the collective endeavour of employees might be understood as a source of learning that can contribute to making strategy should be of little surprise to HRD practitioners. Mintzberg (1987), for example, identified more than 25 years ago how learning from work can become strategic. Given the recognised failure of prescriptive approaches to strategic decisions, learning from within the relationships of everyday employment can give added impetus to what has been recognised as strategy-as-practice (Jarzabkowski and Spee 2009). HRD can mediate the connection to the making of strategic decisions by recognising that informal learning contains the potential for new ideas, products and services that leverage enhanced skills. In such ways HRD through TMD can play a significant role in organisation alignment.

While much effort can be made to enhance economic sustainability through efficiency (Sidani and Ariss 2014), if skill enhancement is to impact on pay a pluralist view must be taken of the forces that affect skill formation and valuation. This requires intelligence of the skill ecosystems within which an organisation sits. Buchanan et al. (2001, p. 21) define skill ecosystems as clusters of high, intermediate or low-level competencies in a particular region or industry shaped by interlocking networks of firms, markets and institutions’. Given the proclivity for such networks to expand globally but also feed a process of agglomeration (Fujita and Thisse 2013), how skills are formed and reproduced does become more dependent on how participants make and present their arguments in dialogic encounters. HRD can play a key part in the building and establishment of networks and partnerships for sustainable skills ecosystems that move skills enhancement towards higher payment (Hall and Lansbury 2006). They can 
do so again as mediators, stepping into the spaces between network participants so that they can thicken the interactions between them (Broadbent 2003). It is only by participating in such moves, both within organisations and within and between a variety of external networks that HRD can embrace the tensions, dilemmas and paradoxes that are inherent in the enactment of the triple bottom line (Garavan and McGuire 2010) in support of CSR and sustainability. Taking the wider view of TMD that we have argued for can provide the crucial link to enhancing an organisation's performance and responsibility to society. In particular, we see the following as crucial features of Sustainable Talent Management Development (S-TMD):

(1) A shift of focus to place a larger emphasis on the social returns to TMD and to appreciate the collective endeavour of work practices

(2) An increased recognition of the socio-economic impact of the organisation and external stakeholders in the development and implementation of TMD

(3) An emphasis on the retention of low-skilled employees to minimise the cost of labour turnover and optimise the return on investment in training and development

(4) Facilitation of the links between learning from within the relationships of everyday employment, skill enhancement and product/service development and decisions on product-market strategies

(5) Identification and participation in skills eco-systems

\section{Towards Sustainability-Focused TMD within the context of the low paid}

In order to further explore the concept of S-TMD we consider its implications for a section of the labour market, the low skilled and low paid, that are at risk of being marginalised in terms of pay and opportunity. The narrow economic view of TMD 
articulated by Capelli (2008), states that talent management exists to support the organisations overall objective 'which in business essentially amounts to making money' (p.3). A wider conceptualisation of TMD to incorporate notions of CSR can lead to S-TMD. Those organisations adopting S-TMD would place a larger emphasis on the social returns to TMD and a greater understanding of the collective aspect of talent enactment. Such organisations would seek to realise wider benefits from an increased CSR reputation that improves employee motivation and customer loyalty with specific policies and practices continuing to provide profitable return to shareholders. The tension between economic and social returns has to be used creatively through a dilemmatic understanding (Billig 1996), which is a skill that HRD must master. This suggests that choice between economic or social returns is a false choice. Any organisation may choose one or the other as a focus but this obscures the dilemma that recognises the interdependence between an economic and social focus. All organisations face such a dilemma, which cannot be solved as a problem of choice but as competing alternatives that must be reconciled (See Hampden-Turner 1994).

Thunnissen et al. (2013) argue that the scope of TMD should be broadened from a limited set of HR practices to a focus on people in their organisation and their work (Boxall and Macky 2009). It is part of our argument that through the enactment of work practices and dependence and interdependence with others, learning will occur quite naturally (Stuart 1984). However, the general view of low skill employment is that it offers low quality work. It is viewed as highly repetitive, offers less pleasant working conditions with limited discretion and intrinsic interest, provides few incentives for further education and training and few real opportunities for progression. In this environment, those doing such work often see little need to develop their human capital since it is outside their experience, their employer does not require higher level skills 
and the opportunities to progress are limited (Lloyd et al. 2008). Whilst employment in low-paid work can bring social, economic and psychological benefits in comparison with being out of work, some have identified that individuals can remain trapped in what have been termed ‘dead end jobs’ (Lloyd and Mayhew 2010). In cases such as this some individuals express fatalism about their prospects and are unable to envision themselves in any other type of work whilst others aspire to improve income but are ambivalent about training or taking on more responsibility at work and fail to reach their potential (Ray et al. 2010). Opportunities for career progression are limited in terms of the proportion of the workforce who can hope to 'move up the career ladder' given increased competition for fewer jobs at a higher level in the organisational pyramid. However, in line with the sentiments underpinning an inclusive and collective approach to TMD, Fuller and Unwin (2008) suggest that individuals at any level of an organisation can develop their skills if they have an opportunity to be involved in more challenging work and work design has a key role to play in the learning and development of workers at all levels.

S-TMD has to accept a pluralist assumption of work relations that is extended to include stakeholders in the external environment and society at large (Christensen et al. 2007). Boudreau and Ramstad (2005) challenge the traditional shareholder paradigm by introducing the argument that organisations should strive for sustainability. Besides financial viability, sustainability includes goals such as diversity, social responsibility, supporting human and employee rights, protecting the environment, contributing to the economy and wider society. This is in tune with other HRD researchers such as Ardichvili (2011) who note the growing importance of research and practical work on the interface of HRD (and by implication TMD), CSR and sustainability. The S-TMD approach incorporates the idea that society at large is confronted with the consequences 
of the way in which organisations manage their employees (Rubery and Grimshaw 2003). In addition to the production of goods and services, organisations offer employment opportunities to citizens and affect the distribution of income that has a significant impact on the wealth and health of localities and nations.

Not for the first time the recent global financial crisis resulting from unbridled profit seeking behaviour has raised the question of whether the world can sustain organisational practices that do not incorporate wider societal responsibilities. Thomas Piketty’s (2014) piercing critique of concentrated capital ownership, which has produced a highly unequal distribution of income, has highlighted this issue once again. HRD, like many other fields of activity have not managed to escape such effects and the primary purpose of TMD remains as a narrowly construed consideration of improved organisational performance based on an exclusive categorisation of employees for TMD activities (CIPD 2013).

Thunnissen et al (2013) identify the need for empirical evidence to support theorising and report a gap in the literature associated with the exit and turnover of talent. Our analysis suggests that some organisations and sectors, particularly those with a large proportion of low paid jobs such as retail and catering, are bedevilled by high rates of labour turnover which adversely impact on their financial performance and productivity at the micro level of the organisation (Booth and Hamer 2007). Stewart (2008) has reported a strong association between TMD and employee retention however many employers appear to consider high labour turnover to be an inevitable consequence and to focus on managing the situation rather than seeking to improve it (Rowley and Purcell 2001).

Examining turnover from the perspective of the low paid worker identifies a significant challenge for the individual and society. Poor employment retention among 
low paid workers feeds 'low pay-no pay cycles' that bind individuals and their families to lives on low, insecure incomes - whether in work or claiming benefits (Shildrick et al. 2010). Adopting S-TMD approach, which recognises the wider impact on society, can lead to the identification of the cost of labour turnover for the individual in terms of reduced household income and for society in terms of the health and welfare costs of unemployment. However case study evidence, and the literature more widely, suggests that only a minority of employers have chosen to reduce the cost of labour turnover and improve the return on investment in employee development by adopting policies and practices that support retention and progression of low paid workers (Devins et al. 2014). We suggest that the S-TMD repertoire needs to shift the appreciation from a low paid and easily expendable resource, which has all too quickly fed the growing Precariat (Lea 2013), to one where learning and skill enhancement and enhanced productivity become much more likely.

There is some evidence associated with the role that education and training plays in the workplace that reflects an emphasis on traditional forms of HRD intervention rather than the learning that occurs through job design and performance at work. Senior managers and decision-makers have choices on the value that is created by their staff (Pfeffer 1995) but if they cannot see the evidence, the cycle of low skill/low pay will persist. The economic returns to training at work may be variable but they appear to benefit both the employer and individual. For example, an OECD review of international literature suggests that organisations realise the majority of the return on employer-funded training with individuals enjoying between $20 \%$ and $50 \%$ of the return in terms of higher pay (Hansson 2008). The positive effects on wages indicate the potential for HRD to help reduce in-work poverty for those benefitting from the training. A study of the effect of learning on low-pay in the UK and the Netherlands 
found that although the countries have very different systems and approaches, training increases the likelihood of moving from low pay to high pay and reduces the likelihood of transition in the other direction from high pay to low pay (Pavlopoulos et al. 2009). In a study by Ray et al. (2010) in the UK, access to learning and development opportunities is identified as a key to progression in the labour market for those in low paid jobs. However, there is some evidence that the processes of polarisation in the labour market are being played out in access to learning opportunities in the workforce. The type of occupational group a worker is in can have a material impact on access to training opportunities at work with low skilled workers less likely to benefit from employer provided training (Field 2009; Mason and Bishop 2010). For those not receiving training a vicious circle arises where those who need the most training to develop their employability and careers receive the least training and subsequently lose their motivation to learn as the pay and career gaps with their peer groups widen. Beyond the negative psychological effects on individual motivation, it maintains a status quo based on a low-skill equilibrium which traps the economy in a low-wage low-skills path and this lack of sustainable development can be devastating for individuals, localities, employers, labour markets and entire sectors of the economy. In order to reflect the pluralistic nature of S-TMD it is valuable to consider further the experiences of low paid employees at work in relation to training and development. In the review of employee demand for training Johnson et al. (2009) suggest that there is evidence that the presence of trade unions has a positive impact on access to training in the workplace. Unions and trade union representatives play a key role both in addressing individual barriers and influencing employer attitudes and practices towards those with lower skills. A S-TMD view would suggest a need to reverse the decline in union involvement in HRD considerations at work in the UK and 
to consider a greater role for social partners and workers councils as is the case in countries such as Germany and Austria. Seeking an extended understanding of an organisation's place in the skills eco-system becomes crucial. S-TMD requires HRD practitioners to look carefully at the constraining features of the networks, markets and institutions that affect skills formation and valuation. This requires a collaborative orientation to reverse the direction low skill/low pay formation. Based on the attempts of skills ecosystem construction in Australia (See Smith 2006), there is a need for partnership approaches accompanied by dialogue between partners. There is the potential for participation of multiple players in the building of a network, but progress can be slow and public sector intervention may be required to act as a catalyst (Hall and Lansbury 2006).

\section{Implications for practice and research}

The emergent and contested nature of sustainability has limited its widespread, systematic application in the fields of HRM and HRD to date (Enhart and Harry 2012). Economic considerations tend to dominate decision-making and the tension between short-term financial profit and more broadly defined social returns remains a characteristic of organisational life. In this paper we have explored an extended and more balanced approach to TMD and the role that it may play in the development of sustainability at the micro and macro levels. We argue that just as physical sustainability considers the consequences of organisational activity for ecological resources, social sustainability considers how activities affect people (Pfeffer 2010) and the external environment within which organisations operate (Enhert and Harry 2012). Our analysis suggests the need to move from a predominantly individualist, managerial and unitarist understanding of TMD to one grounded in the 
value of tacit and embedded development processes undertaken to reflect a pluralist, multi-voiced approach to understanding of a skills eco-system.

We now seek to respond to the questions prompted by Iles et al. (2010) and Iles (2013) which we now adjust as follows:

- What issues is TMD meant to solve?

- What should be the focus of TMD practices?

- What are the implications for those not identified as the talented?

Our analysis, based on what we have called S-TMD, draws attention to the wasted and inefficient use of resources associated with high labour turnover in several sectors of the economy and the economic/psychological costs of low pay -no pay cycles for the individuals experiencing them and for society more generally in terms of the health and welfare costs of unemployment. It has highlighted the generally positive impact of training on employee progression which, implicitly at least, reflects the greater productivity realised by organisations undertaking such activity. At the same time we emphasize the tacit knowledge developed through work that remains largely invisible and untapped when viewed through a traditional HRD/TM lens. The analysis also highlights the requirement for a more appropriate valuation of the benefits of training and learning to both the employer and employee and crucially, S-TMD’s first task is to discover the understanding required to reset the cycle from low skill to enhanced skill and improved productivity. This is a crucial and much needed response to the first question. In this way S-TMD is far more than a utopian ideal and is grounded in improved social and economic performance. 
Responding to the second and third questions, TMD activities have tended to take an individualist and top down perspective, in the form of separate HR activities of recruitment, selection, development and so on which lead to abstracted notions of talents pools, talent pipelines and grids based on performance/potential assessments. This results in the disconnection of TMD activities from work practices and creates the divisions of staff between the talented and untalented. While this meets the requirement for apparently rational choices and decisions by managers, it is also unitarist and gives little possibility of appreciation the pluralist view of work. It also likely to reinforce low skill working and miss the potential for movement away from this position. Both practitioners and researchers must address this imbalance. In particular, TMD theorising needs to adjust its focus away from individuals or positions as units of consideration and show more concern with work as a collective endeavour, consisting of work practices as conjoint action based on dependence and interdependence.

A further task for S-TMD is to provide the flow of knowledge into decisionmaking about which markets to serve on the basis of enhanced skills products and services. As we suggest, prescriptive approaches alone to strategic decisions have long been recognised as deficient. There is a need to complement prescription with learning from the collective endeavour of employees, which needs to become a focus for STMD.

Whilst much of our discussion has centred on the UK context, a lot of the research underpinning it is drawn from international sources and the issues of low pay, productivity and S-TMD resonate in many areas across the globe and has several implications for practice. There is a consensus that the philosophies underpinning TMD, how the concept of TMD is understood and what TMD practices are used are heavily influenced by institutional, cultural, industrial, organizational, and individual 
factors at different levels and any form of local S-TMD will need to take account of these factors.

Much of the CSR and sustainability literature tends to focus on a win-win-win situation where it is argued that productivity benefits stem from improved people skills and deeper loyalty from employees and customers (Buckley et al. 2008). S-TMD has considerable potential in this arena however integrating such ideas into practice is not a simple task and it requires vision, commitment and leadership. How well S-TMD is implemented will be important. Leaders and line managers, in particular, have a key role to play in developing workers, given the limited progression opportunities associated with the hollowed out labour market. Where line managers have the ability to build teams, manage performance and coach staff, they can be key champions of worker development (Devins et al. 2014). However line managers have little or no training in supervision, let alone TMD and opportunities to develop staff, particularly at lower levels can be missed (Hudson et al. 2013).

The analysis in this paper has implications for TMD and results in some practical questions and research avenues to consider. How can talent be conceptualized and measured amongst the low skilled? To what extent can S-TMD ameliorate some of the detrimental effects of short-termism associated with recruitment and retention strategies or poor quality jobs? What role does S-TMD have to play in smaller organisations where resources are non-specialised or largely absent and hierarchical opportunities for progression are limited? S-TMD also presents challenges for researchers and suggests the need for research methodologies that uncover 'hidden knowledge' and reflect a pluralistic nature. One approach, for example, would be conversations as part of an appreciative enquiry to find out what works well in an 
organisation and how (Cooperider and Srivastva 1987). Such a process is generative (Gergen 1987) in both discovering knowledge of the strength and virtue in an organisation but also the possibility of stimulating learning and questioning that can point to skill enhancement and product/service development. There is no magic bullet available to policy makers and organisational decision-makers but perhaps a S-TMD approach offers a way for individuals, organisations and society to pursue the win- winwin situation that many proponents of sustainability promote.

\section{Conclusion}

Over the years researchers have examined whether TMD is a new phenomenon or simply just another management fashion or fad (Iles et al. 2010; Tansley 2011). Unequivocally they conclude that TMD does in fact add value over other strategic human resource management practices with workforce differentiation and segmentation key differentiating factors (Collings and Melahi 2009). TMD differs from SHRM (i.e. the design and implementation of a set of internally consistent policies and practices which ensure that a firms human capital contributes to the achievement of its business objectives) in that it is believed to be less egalitarian and more elitist by definition (Collings and Mellahi 2009). More inclusive approaches to TMD exist and may include low skilled workers although we would point to the need for S-TMD to emphasize and differentiate those in low paid jobs to promote and capture collective learning to contribute to the development of product-market strategies that improve the performance of the organization and make a greater contribution to society more generally.

\section{References}


Ardichvili, A. 2011. "Sustainability of Nations, Communities, Organisations and Individuals: The Role of HRD.” Human Resource Development International 14 (4): 371-374. doi:10.1080/13678868.2011.601570

Atkinson, W. 2010. Class, Individualization and Late Modernity: In Search of the Reflexive Worker. Basingstoke: Palgrave Macmillan.

Autor, D. 2010. The Polarisation of Job Opportunities in the US Job Market. Washington DC: Center for American Progress.

Beckett, D. and P. Hager. 2002. Life, Work and Learning: Practice in Postmodernity, London: Routledge.

Billig, M. 1996. Arguing and Thinking: A Rhetorical Approach to Social Psychology. Cambridge: Cambridge University Press.

Booth, S., and K. Hamer. 2007. "Labour Turnover in the Retail Industry: Predicting the Role of Individual, Organisational and Environmental Factors.” International Journal of Retail \& Distribution Management 35(4): 289 - 307. doi:10.1108/09590550710736210

Boudreau, J.W., and P.M. Ramstad. 2005. "Talentship, Talent Segmentation and Sustainability. A New HR Decision Science Paradigm for a New Strategy Definition." In The Future of Human Resource Management, edited by M. Losey, S. Meisinger, and D. Ulrich, 293-303. New Jersey: Wiley and Sons.

Boxall, P., and K. Macky. 2009. "Research and Theory on High Performance Work Systems. Progressing the High-Involvement Stream.” Human Resource Management Journal 19(1): 3-23. doi: 10.1111/j.1748-8583.2008.00082.x

Broadbent, J. 2003. "Movement in Context: Thick Networks and Japanese Environmental Protest”. In Social Movements and Networks, edited by M. Diani and D. McAdam, 204-29. Oxford: Oxford University Press.

Brockmann, M., L. Clarke, and C. Winch. 2011. European Skills and Qualifications: Towards a European Labour Market. London: Routledge.

Buchanan, J., K. Schofield, C. Briggs, G. Considine, P. Hager, G. Hawke, J. Kitay, G. Meagher, J Macintyre, A. Mounier, and S. Ryan. 2001. Beyond Flexibility: Skills and Work in the Future. Sydney: New South Wales Board of Vocational Education and Training.

Buchanan, J., L., S. Scott, H. Yu, H. Shutz, and M. Jakubauskas. 2010. Skills Utilisation - An Overview of Current Approaches to Measurement and Improvement. Workplace Research Centre, University of Sydney.

Buckley, G., M. Herinques, and J.M. Salazar-Xirinachs. 2008. The Promotion of Sustainable Enterprises. Geneva: International Labour Organisation.

Burbach, R., and T. Royle. 2010. "Talent on Demand? Talent Management in the German and Irish Subsidiaries of a US Multinational Corporation.” Personnel Review 39(4): 414-431. doi: 10.1108/00483481011045399

Capelli, P. 2008. "Talent Management For The Twenty-First Century." Harvard Business Review 86(3): 74-81.

Cerdin, J-L., and C. Brewster. 2014. Talent Management and Expatriation: Bridging Two Streams of Research and Practice. Journal of World Business 49(2): 245252. doi: 10.1016/j.jwb.2013.11.008

Christensen, T., P. Laegrid, P.G. Roness, and K.A. Rovik. 2007. Organization Theory for the Public Sector: Instrument, Culture and Myth. New York: Taylor and Francis.

Chuai, X., D. Preece, and P. Iles. 2008. "Is Talent Management Just "Old Wine in New Bottles?: The Case of Multinational Companies in Beijing.” Management Research News 31(12): 901 - 911. doi: 10.1108/01409170810920611 
CIPD. 2013. Learning and Talent Development Survey. London: Chartered Institute of Personnel and Development.

CIPD. 2014. "Talent Management, HR Topics". Chartered Institute of Personnel Development. Accessed May 23. http://www.cipd.co.uk/hr-topics/talentmanagement.aspx

Collings, D.G., and K. Mellahi. 2009. "Strategic Talent Management. A Review and Research Agenda.” Human Resource Management Review 19 (4): 304-313. doi: 10.1016/j.hrmr.2009.04.001

Collins, H.M. 2001. "Tacit Knowledge, Trust, and the Q of Sapphire.” Social Studies of Science,31(1): 71-85. doi: 10.1177/030631201031001004

Cooke, F.L., D.S. Saini, and J. Wang. 2014. "Talent Management in China and India: A Comparison of Management Perceptions And Human Resource Practices.” Journal of World Business 49(2): 229-235. doi: 10.1016/j.jwb.2013.11.006

Cooperrider, D.L., and S. Srivastva. 1987. "Appreciative Inquiry in Organizational Life.” In Research in Organizational Change and Development, edited by R.W. Woodman, and W.A. Pasmore, 129-169. Stamford, CT: JAI Press.

Farndale, E., H. Scullion, and P. Sparrow. 2010. "The Role of the Corporate HR Function in Global Talent Management.” Journal of World Business, 45(2): 161168. doi: 10.1016/j.jwb.2009.09.012

Fuller, A., and L. Unwin. 2008. “Towards Expansive Apprenticeships”. Teaching and Learning Research Programme, London. Accessed May 1. http://www.tlrp.org/pub/documents/apprenticeshipcommentaryfinal.pdf

Bickerstaffe, B. Mitchell and S. Halliday. 2014. Progression of Low-Paid Workers in the Retail, Catering and Case Sectors of the Economy. York: Joseph Rowntree Foundation.

Enhert, I., and W. Harry. 2012. "Recent Developments and Future Prospects on Sustainable Human Resource Management.” Management Revue 23(3): 221238. doi: 10.1688/1861-9908_mrev_2012_03_Ehnert

Felstead, A., D. Gallie, F. Green., and Y. Zhou. 2007. Skills at Work 1986-2006. Universities of Oxford and Warwick: SKOPE.

Field, J. 2009. “Lifelong Learning in Scotland: Cohesion, Equity and Participation.” Scottish Educational Review 41(2): 4-19.

Fujita, M., and J-F. Thisse. 2013. Economics of Agglomeration: Cities, Industrial Location, and Globalization. Cambridge: Cambridge University Press.

Gallardo-Gallardo, E., N. Dries, and T.F. Gonzalez-Cruz. 2013. "What is the Meaning of 'Talent' in the World of Work?” Human Resource Management Review 23(4): 290-300. doi: 10.1016/j.hrmr.2013.05.002

Gallie, D. 2007. "Production Regimes, Employment Regimes and the Quality of Work." In Employment Regimes and the Quality of Work, edited by D. Gallie, 1-34. Oxford: Oxford University Press.

Garavan, T.N., and D. McGuire. 2010. "Human Resource Development and Society: Human Resource Development's Role in Embedding Corporate Social Responsibility, Sustainability and Ethics in Organizations.” Advances in Developing Human Resources 12(5): 487-507. doi: 10.1177/1523422310394757

Gergen, K. J. 1978. “Towards Generative Theory.” Journal of Personality and Social Psychology 36(11): 1344 - 1360.

Gouldon, C. 2010. Cycles of Poverty, Unemployment and Low Pay. Research Roundup. York: Joseph Rowntree Foundation.

Gronn, P. 2002. "Distributed Leadership as a Unit of Analysis.” Leadership Quarterly 13(4): 423-451. doi: 10.1016/S1048-9843(02)00120-0 
Hall, R., and R.D. Lansbury. 2006. "Skills in Australia: Towards Workforce Development and Sustainable Skill Ecosystems.” Journal of Industrial Relations 48(5): 575-592. doi: : 10.1177/0022185606070106

Hampden-Turner, C. 1994. Charting the Corporate Mind: From Dilemma to Strategy. Oxford: Blackwell.

Hansson, B. 2008. Job-Related Training and Benefits for Individuals: A Review of Evidence and Explanations. OECD Education Working Paper 19. Paris: Organisation for Economic Cooperation and Development.

Hudson, M., G. Netto, F. Sosenko, M. Noon, P. de Lima, A. Gilchrist, and , N. Kamenou-Aigbekaen. 2013. In-work Poverty, Ethnicity and Workplace Cultures. York: Joseph Rowntree Foundation

Iles, P., D. Preece, and X. Chuai. 2010. "Is Talent Management A Management Fashion in HRD? Towards a Research Agenda." Human Resource Development International 13(2): 125-145. doi: 10.1080/13678861003703666

Iles, P. 2013. Commentary on "The Meaning of 'Talent' in the World Of Work." Human Resource Management Review 23(4): 301-304. doi: 10.1016/j.hrmr.2013.08.002

ILO. 2013. “Global Wage Report”. International Labour Organisation. Accessed May 1. http://www.ilo.org/global/research/global-reports/global-wagereport/2012/WCMS_194843/lang--en/index.htm

Jarzabkowski, P., and Spee P.A. 2009. "Strategy-As-Practice: A Review and Future Directions for the Field.” International Journal of Management Reviews 11(1): 69-75. doi: 10.1111/j.1468-2370.2008.00250.x

Johnson, S., S. Sawicki, C. Pearson, C. Lindsay, R.W. McQuaid, and M. Dutton. 2009. "Employee Demand for Skills: a Review of Evidence and Policy”. UK Commission for Employment and Skills. Accessed May 9. http://dera.ioe.ac.uk/9116/2/Evidence_Report_3_3.pdf

Lea, J. 2013. "From Denizen to Citizen and Back: Governing the Precariat Through Crime.” Criminal Justice Matters 93(1): 4-5.

Lewis, R. and R. Heckman. 2006. “Talent Management: A Critical Review.” Human Resource Management Review 16(2): 139-154. doi: 10.1016/j.hrmr.2006.03.001

Lloyd, C., and K. Mayhew. 2010. Skill: The Solution to Low Wage Work? Industrial Relations Journal 41(5): 429-445. doi: 10.1111/j.1468-2338.2010.00578.x

Lloyd, C., G. Mason, and K. Mayhew. 2008. Low-Wage Work in the United Kingdom. New York: Russell Sage Foundation,

Martin, J, and C. Schmidt. 2010. "How to keep your top talent”. Harvard Business Review. Accessed May 14. http://www.learning2connect.com.sites/default/files/Martin-2010How\%20to\%20keep\%20your\%20high\%20quality\%20talent-HBR.pdf.

Mason, G. and K. Bishop. 2010. “Adult Training, Skills Updating and Recession in the UK: The Implications for Competitiveness and Social Inclusion”. Centre for Learning and Life Chances in Knowledge Economies and Societies. Accessed May 6. http://www.llakes.org/wp-content/uploads/2010/08/T.-Adult-TrainingSkills-Updating-and-Recession.pdf

Michaels, E., H. Handfield-Jones, and B. Axelrod. 2001. The War for Talent. Harvard Boston, MA: Business School Press.

Mintzberg, H. 1987. “Crafting Strategy.” Harvard Business Review July-August: 6675. 
OECD (1996) Employment Outlook 1996. Paris:Organisation for Economic Cooperation and Development,

Okay-Somerville, B. and D. Scholarios. 2013. "Shades of Grey: Understanding Job Quality in Emerging Graduate Occupations.” Human Relations 66(4): 555-585. doi: $10.1177 / 0018726712465094$

Paawe, J. 2007. HRM and Performance: In Search of Balance. Tilburg: Tilburg University.

Pavlopoulos, D., R. Muffels, and J.K. Vermunt. 2009. "Training and Low-Pay Mobility: The Case of the UK and the Netherlands." Labour 23(1): 37-59. doi: 10.1111/j.1467-9914.2008.00438.x

Pennycook, M., and M. Whittaker. 2012. Low Pay Britain 2012. London: Resolution Foundation.

Pfeffer, J. (2010) Building Sustainable Organisations: The Human Factor. Academy of Management Perspectives 24(1): 34-45

Pfeffer, J. 1995. "People, Capability and Competitive Success.” Management Development Review 8(5): 6-11. doi: 10.1108/09622519510771942

Philpott, J. 2014. Rewarding Work For Low-Paid Workers. York: Joseph Rowntree Foundation

Piketty, T. 2014. Capital in the Twenty First Century. Cambridge: Harvard Business School Press.

Plunkett, J., and A. Hurrell. 2013. Fifteen Years Later - A Discussion Paper on the Future of the UK. London: National Minimum Wage and Low Pay Commission/ Resolution Foundation.

Ray, K., L. Hoggart, S. Vegeris and R. Taylor. 2010. Better Off Working? Work, poverty and Benefit Cycling. York: Joseph Rowntree Foundation.

Redford, K. 2005. “Shedding light on talent tactics.” Personnel Today, 26, September, p22.

Rubery, J., and D. Grimshaw. 2003. The Organisation of Employment. An International Perspective. Basingstoke: Palgrave Macmillan.

Shildrick, T., R. MacDonald, C. Webster, and K. Garthwaite. 2010. The Low-pay, Nopay Cycle: Understanding Recurrent Poverty. York. Joseph Rowntree Foundation.

Sidani, Y., and A. Al Ariss. 2014. "Institutional and Corporate Drivers of Global Talent Management: Evidence from the Arab Gulf Region.” Journal of World Business 49(2): 216-224. doi: 10.1016/j.jwb.2013.11.005

Smith, B. (2006) “What Makes a Successful Skill Ecosystem?” New South Wales Technical and Further Education Commission. Accessed May 26. http://lrrpublic.cli.det.nsw.edu.au/lrrSecure/Sites/Web/13289/ezine/year_2006/feb apr/feature_ecosystem.htm

Sonnenberg, M, V. van Zijderveld, and M. Brinks. 2014. “The Role Of TalentPerception Incongruence in Effective Talent Management.” Journal of World Business 49(2): 272-280. doi: 10.1016/j.jwb.2013.11.011

Spillane, J.P. 2006. Distributed Leadership. San Francisco, CA: Jossey-Bass.

Stewart, J. 2008. Developing Skills Through Talent Management. Wath-upon-Dearne: UK Commission for Employment and Skills.

Stuart, R. 1984. “Towards Re-Establishing Naturalism in Management Training and Development.” Industrial and Commercial Training 16(4): 19-21. doi: 10.1108/eb003979 
Tansley, C., P.A. Turner, C. Foster, L.M. Harris, J. Stewart, A. Sempik, and H. Williams. 2007. Talent: Strategy, Management and Measurement. London. CIPD.

Tansley, C. 2011. “What Do We Mean By The Term 'Talent' In Talent Management?” Industrial and Commercial Training 43(5): 266-274. doi: 10.1108/00197851111145853

Thunnissen, M., P. Boselie, and B. Fruytier. 2013. "Talent Management and the Relevance of Context: Towards a Pluralistic Approach.” Human Resource Management Review 23(4): 326-336. doi: 10.1016/j.hrmr.2013.05.004

UKCES. 2009. Ambition 2020: World Class Skills and Jobs for the UK. Key Findings and Implications for Action. The 2009 Report. Wath-upon-Dearne:UK Commission for Employment and Skills,

Van Marrewijk, M. 2003. "Concepts and Definitions of CSR and Corporate Sustainability: Between Agency and Communion.” Journal of Business Ethics, 44(2/3): 95-105. doi: 10.1023/A:1023331212247

Wilson, R., and T. Hogarth. 2003. Tackling the Low Skills Equilibrium. London: Department of Trade and Industry.

\section{Acknowledgements}

The authors would like to thank our colleague at Leeds Metropolitan University Tim Bickerstaffe for his contribution to an initial draft of this paper and the anonymous reviewers and editors for their insights and helpful suggestions. 